\title{
REVIEW
}

\section{TOOLS FOR IDENTIFICATION OF NURSES' EXPERIENCES OF INPATIENT AGGRESSION}

\author{
Zuzana Kadlčková1, Martina Tomagová ${ }^{2}$ \\ ${ }^{1}$ Department of Nursing and Midwifery, Faculty of Medicine, University of Ostrava, Ostrava, Czech Republic (student) \\ ${ }^{2}$ Department of Nursing, Jessenius Faculty of Medicine in Martin, Commenius University in Bratislava, Slovakia
}

Received November 20, 2017; Accepted April 17, 2018. Copyright: This is an open access article distributed under the terms of the Creative Commons Attribution International License (CC BY). http://creativecommons.org/licenses/by/4.0/

\begin{abstract}
Aim: The objective of this review study was to find quantitative research studies that describe nurses' experiences of aggression using scales, and to provide an introduction to these evaluation tools. Design: A review study. Method: Research studies were searched for using keywords in the licensed electronic bibliographic databases CINAHL, Academic Search Complete (EBSCOhost), SCOPUS, PubMed, and Medline from January to May 2017. Results: From the fifty-two found, six relevant studies were included. For the purpose of gaining information about nurses' experiences of inpatient aggression, the following tools were used in these studies: the Violent Incident Form; the Overt Aggression Scale; the Perceptions of Prevalence of Aggression Scale; the Violence and Aggression of Patients Scale; the Survey of Violence Experienced by Staff (German Version-Revised); and Workplace violence. Conclusion: Several reliable measuring tools have been developed for the purpose of measuring nurses' experiences of inpatient aggression. They differ in many characteristics, making comparison of the results found using these measuring tools somewhat more difficult. Another limitation is that the tools assess nurses' experiences of aggressive behavior over the period of the previous 12 months, which might affect the accuracy of respondents' memory. These tools are an important method of gaining data on nurses' experiences of inpatient aggression; however, they do not provide precise objective data on patient aggression in clinical practice.
\end{abstract}

Keywords: aggression, experience, hospitalization, measuring tool, nurse, patient.

\section{Introduction}

Aggression in healthcare settings is a complex problem that affects patient outcomes and worker health, and requires careful consideration in terms of measurement, monitoring, and intervention to reduce aggressive patient behavior (Iennaco et al., 2013). Nurses, in comparison with other groups of healthcare workers, are most at risk from the aggressive behavior of hospitalized patients (Lepping et al., 2013). The experiences of nurses of various forms of patient aggression, its risk factors, and the frequency of its occurrence, as well as the opinions of nurses on inpatient aggression, have been investigated and discussed for several decades (Lanza, 1983; Rippon, 2000). Nurses' experiences of patient aggression can be measured using two methods - qualitative and quantitative. In research on these issues, quantitative methods are predominantly applied (Stevenson et al., 2015), one of which is the use of a measuring tool (Speroni et al., 2014), whereby nurses report occurrences of inpatient

Corresponding author: Zuzana Kadlčková, Department of Nursing and Midwifery, Faculty of Medicine, University of Ostrava, Syllabova 19, Ostrava, Czech Republic; email: zkadlckova@centrum.cz. aggression which they have experienced (Iennaco et al., 2013). Several different measuring tools have been developed to measure these experiences. The results obtained with these measuring tools are often the basis for further research in this field, such as the study of the relationship between inpatient aggression and job satisfaction in nurses (Gurková et al., 2015), or the analysis of factors influencing the occurrence of aggressive behavior as reported by nurses (Sato et al., 2013). Taylor and Rew (2011) therefore point out the need to use a valid and reliable measuring tool to support the quality of research on identifying the incidence of patient aggression towards nurses in different clinical settings, the effectiveness of preventive programs, and the use of different methods to reduce various forms of aggressive patient behavior.

The occurrence of inpatient aggression towards nurses in the Czech Republic is a serious problem, which has been highlighted by several authors, e.g., Pekara, Trešlová (2011), Pekara (2013). As part of the research project "Násilí na pracovišti v oblasti zdravotnických a sociálních služeb v České republice" (Workplace violence in healthcare and social services in the Czech Republic), Brůha, 
Břeňková, Štěpánková (2005) analyze the causes and various factors affecting the emergence and existence of violence in workplaces. Zacharová (2009) emphasizes the need to prepare health care professionals for contact and communication with anaggressive patient and, in addition, summarizes the basic principles of professional behavior. Čabanová, Dobiášová, Hnilicová (2005) carried out an extensive study in the Czech Republic, focusing on mapping the situation in the field of workplace aggression in the healthcare industry. The study focused on investigating the occurrence of all forms of violence, and was carried out using a Czech version of the Workplace violence (WPV) tool. The occurrence of patient aggression in selected workplaces in the Czech Republic was also researched by Szkanderová, Jarošová (2008) using a measuring tool of their own design. They draw attention to the topicality of this problem.

\section{Aim}

The aim of this review study was to find quantitative research studies that describe nurses' evaluation of aggression using scales, and to provide an introduction to these evaluation tools.

\section{Methods}

\section{Design}

Review study.

\section{Eligibility criteria}

Based on the objective of the review study, the following criteria were set: the full text of a research study published between 1990 and 2017, studies published in English, and reviewed research studies. The time period was chosen due to the growth in research into the issue of inpatient aggression towards nurses over this period.

\section{Sources}

The licensed electronic bibliographic databases CINAHL, Academic Search Complete (EBSCOhost), SCOPUS, PubMed, and Medline were used to obtain relevant research studies for analysis.

\section{Search}

The search for relevant articles was conducted between January and May 2017. The following keywords were used to find relevant sources: aggression, violence, patient, experience, nurse, and tool. The Boolean operators "OR" and "AND" were used, as well as quotation marks before and after the phrase "aggression of patient", to ensure results contained this particular phrase. In each database, the same search criteria were applied. Gradual elimination of studies according to PRISMA recommendations was used. The process of selecting the studies is outlined in Figure 1 (Classification of studies on the investigation of nurses' experience of inpatient aggression using a measuring tool). After a thorough study of the 52 records found using the databases, 23 were discarded. After eliminating duplicates, 29 records were verified. We removed 17 records and selected 12 articles as suitable for further processing. Six were included in the quantitative study. Articles published outside the specified time period, abstracts, duplicates, studies published in a language other than English, theoretical articles, book publications, and publications in a collection were excluded. We also discarded studies in which the tool was not clearly characterised, or which did not include a description of the sample. Finally, we excluded studies that researched the occurrence of aggression in environments other than hospitals, and studies that focused on aggression from relatives, or other health care employees, towards nurses.

\section{Study selection}

The relevant studies were critically examined, the measuring tool for assessing nurses' experience of inpatient aggression was analyzed, and various forms of patient aggression toward nurses were identified. The data obtained was compiled in the form of a table of comparison.

\section{Data analyses}

The analysis and review included a total of six studies: three cross-sectional studies, one longitudinal study, one prospective survey and one study without precise design characteristics.

\section{Results}

Of the selected research studies, six were included in the final analysis. In Table 1 (Table 1 Overview of research studies aimed at determining nurses' experience with inpatient aggression using measuring tools), we include the authors of these studies, the surveyed sample of respondents, the measuring tool used to identify nurses' experience of aggression from hospitalized patients, its reliability, and the particular experience of patient aggression identified. In the analyzed studies published between 1990 and 2017, the measuring tools used were: the Violent Incident Form (VIF) (Arnetz, 1998); the Overt Aggression Scale (OAS) (Yudofsky et al., 1986); the Perceptions of Prevalence of Aggression Scale (POPAS) (Oud, 2001); Výskyt agrese pacientů vůči sestrám (VAPS) (Violence and Aggression of Patients Scale) (Lepiešová et al., 2012); the Survey 


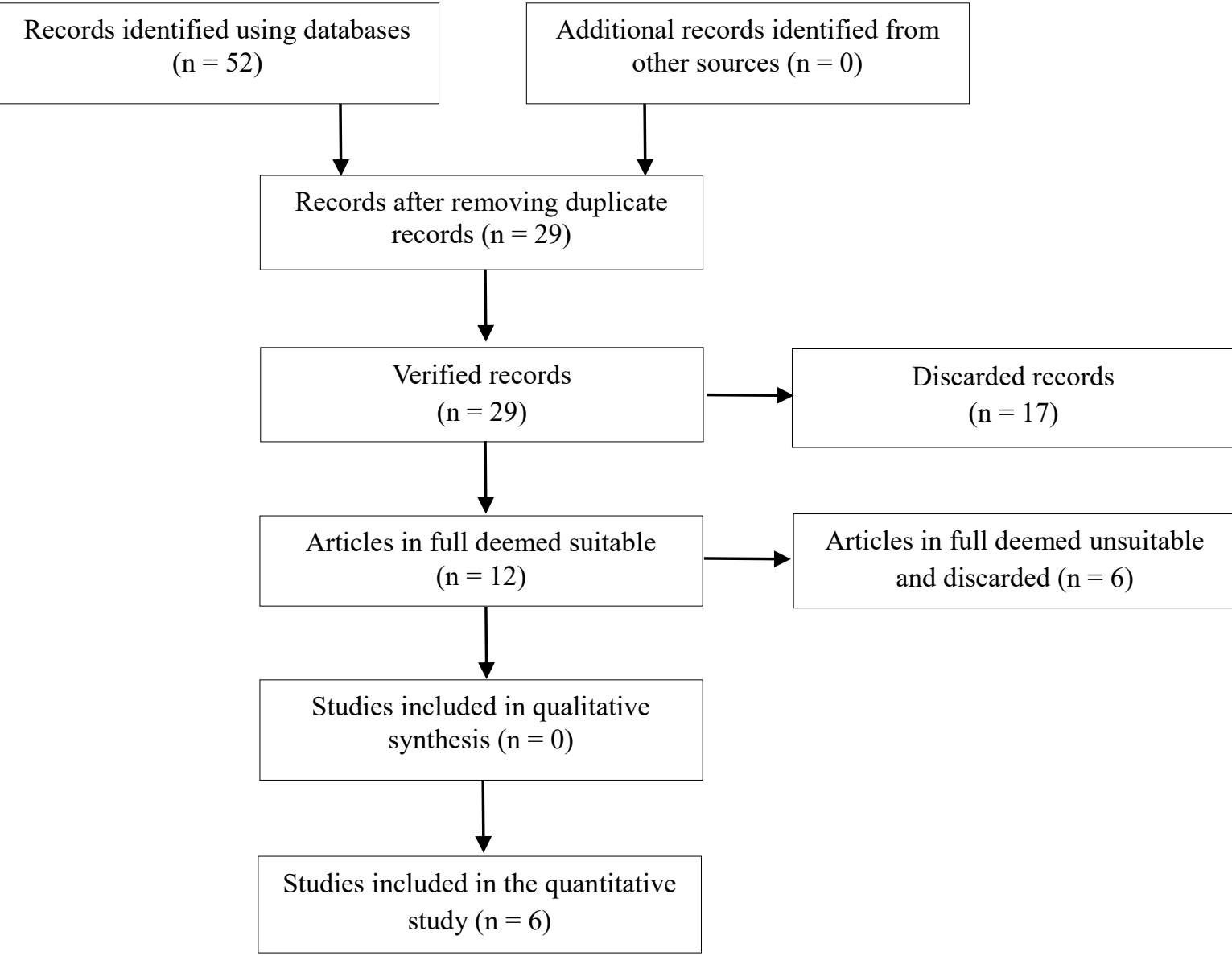

Figure 1 Classification of studies on the investigation of nurses' experience of inpatient aggression, using a measuring tool

of Violence Experienced by Staff (German VersionRevised) (SOVES-G-R) (Hahn et al., 2010, Hahn et al., 2011); and Workplace violence (WPV) (International Labour Office, International Council of Nurse WHO, Public Services International, 2003). We found that in all of the studies listed in Table 1 (Table 1 Overview of research studies aimed at determining nurses' experience of inpatient aggression using measuring tools) the authors measured nurses' experience of inpatient aggression for the previous 12 months of their clinical practice.

Magnavita (2014) examined the occurrence of aggression in two hospitals in Italy in a long-term study. He was interested in the occurrence of aggression over a 12-month period in relation to work-related stress between 2004 and 2009. 698 workers were interviewed, of whom 419 were nurses, before their regular preventive check-up by their employer. Using selected measuring tools, their level of work-related stress was assessed, as well as anxiety and depression, and mental health. Meanwhile, the frequency of patient aggression towards them in the previous 12 months of clinical practice was identified. The Violent Incident Form (VIF) questionnaire by Arnetz (1998) was used to record incidences of aggression involving patients. This questionnaire contains 25 questions in three subscales related to the occurrence of physical and non-physical aggression. Nurses described their experiences of aggression using a four-point Likert Scale. In particular, in subscales number 1 and 2, respondents described their experiences using a frequency scale from 1 - "I have never experienced aggression" to 4 - "I often encounter aggression". In subscale number 3, respondents used the Likert Scale to express the degree of agreement from 1 - "strongly disagree" to 4 - "strongly agree". The questionnaire shows good reliability (SpearmanBrown Coefficient 0.91) (Magnavita, Heponiemi, 2011). Magnavita (2014) found that nurses in the assessed time period had more experience of nonphysical aggression than physical aggression. However, in the period under review, experience of physical aggression from patients was a rising trend. 
Table 1 Overview of research studies aimed at determining nurses' experience of inpatient aggression, using measuring tools

\begin{tabular}{|c|c|c|c|c|}
\hline $\begin{array}{l}\text { Authors of the } \\
\text { study (Year) } \\
\text { Country } \\
\text { Design of study } \\
\end{array}$ & $\begin{array}{l}\text { Set of respondents/ } \\
\text { Number of nurses / } \\
\text { Clinical workplace }\end{array}$ & Measuring tool & Reliability & $\begin{array}{l}\text { Nurses' experience of patient } \\
\text { aggression }\end{array}$ \\
\hline $\begin{array}{l}\text { Vanderslott } \\
\text { (1998) } \\
\text { United Kingdom } \\
\text { Prospective } \\
\text { survey }\end{array}$ & $\begin{array}{l}\text { nurses }=164 \\
\text { psychiatric ward, } \\
\text { children's ward, } \\
\text { geriatric ward }\end{array}$ & $\begin{array}{l}\text { Overt Aggression Scale } \\
\text { (OAS) }\end{array}$ & Cronbach $\alpha 0.87$ & $\begin{array}{l}\text { verbal assault } 15(9 \%) \\
\text { physical aggression towards } \\
\text { objects } 5(3 \%) \\
\text { physical aggression towards } \\
\text { people } 144(88 \%)\end{array}$ \\
\hline $\begin{array}{l}\text { Nijman et al. } \\
\text { (2005) } \\
\text { United Kingdom } \\
\text { Study design not } \\
\text { stated }\end{array}$ & $\begin{array}{l}\text { nurses }=154 \\
\text { acute psychiatric } \\
\text { ward, psychiatric } \\
\text { intensive care units, } \\
\text { rehabilitation unit, } \\
\text { gerontopsychiatric } \\
\text { ward, forensic ward }\end{array}$ & $\begin{array}{l}\text { Perceptions of } \\
\text { Prevalence of } \\
\text { Aggression Scale } \\
\text { (POPAS) }\end{array}$ & Cronbach $\alpha 0.86$ & $\begin{array}{l}\text { verbal aggression } 131(89 \%) \\
\text { threatening verbal aggression } 121 \\
(82 \%) \\
\text { humiliation } 116(78 \%) \\
\text { provocative aggressive behaviour } \\
117(79 \%) \\
\text { passive aggression } 124(84 \%) \\
\text { threatening physical behavior } 122 \\
(82 \%) \\
\text { destructive aggressive behavior } \\
128(86 \%) \\
\text { mild physical violence } 112(76 \%) \\
\text { severe physical violence } 24(16 \%) \\
\text { mild self-violence } 124(84 \%) \\
\text { sexual intimidation / Harassment } \\
100(68 \%) \\
\text { sexual assault / rape } 4(3 \%)\end{array}$ \\
\hline $\begin{array}{l}\text { Hahn et al. (2012) } \\
\text { Switzerland } \\
\text { Cross-sectional } \\
\text { study }\end{array}$ & $\begin{array}{l}\text { nurses }=2,495 \\
\text { department of general } \\
\text { university hospitals }\end{array}$ & $\begin{array}{l}\text { Survey of Violence } \\
\text { Experienced by Staff } \\
\text { German Version-Revised } \\
\text { (SOVES-G-R) }\end{array}$ & good reliability & $\begin{array}{l}\text { verbal aggression } 1145(45.9 \%) \\
\text { threats } 390(15.6 \%) \\
\text { physical aggression } 422(16.9 \%)\end{array}$ \\
\hline $\begin{array}{l}\text { Magnavita (2014) } \\
\text { Italy } \\
\text { Longitudinal } \\
\text { study }\end{array}$ & $\begin{array}{l}\mathrm{n}=698 \\
\text { nurses }=419 \\
2 \text { hospitals }\end{array}$ & $\begin{array}{l}\text { Violent Incident } \\
\text { Form (VIF) }\end{array}$ & $\begin{array}{l}\text { good reliability } \\
\text { (0.91 Spearman- } \\
\text { Brown Coefficient) }\end{array}$ & $\begin{array}{l}\text { physical aggression } \\
\text { in 2004: } 59(8.5 \%) \\
\text { in 2006: } 66(9.5 \%) \\
\text { in 2009: } 81(11.6 \%) \\
\text { non-physical aggression } \\
\text { in 2004: } 164(23.5 \%) \\
\text { in 2006: } 201(28.8 \%) \\
\text { in 2009: } 157(22.5 \%)\end{array}$ \\
\hline $\begin{array}{l}\text { Jiao et al. (2015) } \\
\text { China } \\
\text { Cross-sectional } \\
\text { study }\end{array}$ & $\begin{array}{l}\text { nurses }=588 \\
\text { department of internal } \\
\text { medicine, surgery, } \\
\text { gynaecology, } \\
\text { obstetrics, intensive } \\
\text { care, urgent care }\end{array}$ & $\begin{array}{l}\text { Workplace violence } \\
\text { (WPV) }\end{array}$ & good reliability & $\begin{array}{l}\text { physical aggression } 46(7.8 \%) \\
\text { non-physical aggression } 423 \\
(71.9 \%)\end{array}$ \\
\hline $\begin{array}{l}\text { Lepiešová et al. } \\
(2015) \\
\text { Slovakia, } \\
\text { Cross-sectional } \\
\text { study }\end{array}$ & $\begin{array}{l}\text { nurses }=1,042 \\
\text { department of internal } \\
\text { medicine, surgery, } \\
\text { intensive care }\end{array}$ & $\begin{array}{l}\text { Výskyt agrese pacientů } \\
\text { vǔči sestrám (Violence } \\
\text { and Aggression of } \\
\text { Patients Scale) (VAPS) }\end{array}$ & Cronbach $\alpha 0.86$ & $\begin{array}{l}\text { verbal aggression } 96.8 \% \\
\text { physical aggression } 83.3 \% \\
\text { sexual aggression } 67.7 \%\end{array}$ \\
\hline
\end{tabular}

$n$-absolute frequency

Vanderslott (1998) tracked the degree and extent of violence against nurses in a NHC Trust Hospital in the UK. His survey focused on aggressive incidents recorded by 164 nurses using the Overt
Aggression Scale questionnaire (OAS) (Yudofsky et al., 1986). The OAS categorises the degree and severity of not only physical, but also verbal aggression. The original OAS questionnaire included 
four subscales aimed at identifying demographic data, verbal aggression (four questions), physical aggression against people (four questions), and intervention (the respondents described how they resolved the situation - choosing from 11 possibilities, e.g., not dealing with the situation in any way, talking to the patient, using restrictions, etc.), and at the end they could leave a comment related to the topic (Silver, Yudofsky 1991).

In his study, Vanderslott (1998) used the OAS with three subscales focusing on demographic data, verbal aggression, physical aggression towards objects, and physical aggression towards healthcare workers. These subscales were independently evaluated. Each subscale had four degrees of severity - non-serious (no injury), mild aggression, average aggression and severe aggression. The sum of the scores for each subscale generated an overall score for aggression for each incident. The validity and reliability of the questionnaire was demonstrated by Yudofsky et al. (1986) and also other authors (Morrison, 1993). Vanderslott (1998) identified a significant incidence of physical aggression by patients against nurses $(88 \%)$ versus verbal aggression (9\%) or aggression towards objects.

Nijman et al. (2005) focused on psychiatric nurses' experiences of aggression in terms of the number of days of work missed due to the aggressive behavior of patients in the previous 12 months. The study was conducted in a hospital in London. The Perceptions of Prevalence of Aggression Scale (POPAS) (Oud, 2001) was used during the research, a measuring tool with proven reliability (Cronbach $\alpha$ 0.86) (Nijman et al., 2005). The original POPAS did not contain subscales, and consisted of 15 questions focusing on aggressive behavior with more detailed definitions and descriptions. Nurses recorded the occurrence of aggression using a five-point Likert scale from 1 to 5 (1 indicating that they had never experienced aggressive behavior, and 5 that they often experience aggressive behavior from patients). The results confirmed the authors' assumption that nurses in psychiatric wards are significantly exposed to aggressive events: $89 \%$ to verbal aggression, and $76 \%$ to mild physical violence. In addition to identifying specific types of aggressive behavior, they also recorded threats of aggression made by patients. Verbal threats of aggression were reported by $82 \%$ of nurses, and threatening physical behavior was also reported by $82 \%$.

Lepiešová et al. (2015) mapped nurses' experience of individual forms of inpatient aggression in various hospital departments in the Slovak Republic, during their previous year of practice. 1,042 nurses evaluated their experiences of individual forms of aggression using the Výskyt agrese pacientů vůči sestrám VAPS (Violence and Aggression of Patients Scale) questionnaire (Lepiešová et al., 2012). The questionnaire consists of 11 questions representing individual types of aggressive behavior categorized in three subscales: verbal aggression, physical aggression without the use of a weapon, physical aggression using an offensive weapon, and contact forms of sexual aggression. Nurses recorded their experiences of aggression using a six-point Likert scale. The VAPS is a reliable tool (Cronbach $\alpha$ 0.86) (Lepiešová et al., 2012). The results indicated that up to $96.8 \%$ of nurses in the examined group had experienced verbal aggression, and $83.3 \%$ physical aggression. Nurses recorded verbal attacks from patients as the most common experience, whereas the least common experience was sexual assault (Lepiešová et al., 2015).

Hahn et al. (2012) surveyed the incidence of patient and visitor aggression towards nurses during the previous 12 months at a Swiss General Hospital. 2,495 nurses responded using the Survey of Violence Experienced by Staff questionnaire, German VersionRevised (SOVES-G-R) (Hahn et al., 2010; Hahn et al., 2011), during the period May-July 2007. In 2010, Hahn et al. created the German version of SOVES-G, and verified its validity in Germany, Austria and Switzerland. SOVES-G-R includes 15 questions divided into seven subscales $(A-G)$ : A - demographic data; B - experience of inpatient aggression and visitor aggression in your professional life; $\mathrm{C}$ - experiences of specific types of aggressive behavior (for example threats, physical aggression, verbal aggression) in the previous 12 months; $\mathrm{D}$ - experience of aggression during the previous week; $\mathrm{E}$ - formal procedures after the experience and their consequences; F - available support systems; and $\mathrm{G}$ - training content and the need for intervention skills in practice. Respondents described the frequency of occurrence, and type of aggression over the previous 12 months, and in the previous workweek. The authors noted the good validity and reliability of the tool (Hahn et al., 2011). The results of the study revealed a high incidence of verbal aggression, and a lesser incidence of physical aggression.

Jiao et al. (2015) examined the prevalence of patient violence against nurses in their retrospective crosssectional study. The aim of their study was to determine the prevalence of violence against nurses in the workplace, and to identify risk factors for its occurrence as a basis for interventions aimed at its reduction. 
The study was conducted in seven selected hospitals in China during the period July-September 2013. 588 nurses took part in the research using the Workplace violence in the health sector (WPV) questionnaire (International Labour Office et al., 2003). The questionnaire is an extensive tool developed within the Workplace Violence program in the health sector. It consists of five parts (A-E): Demographics and Workplace Information (19 questions); Physical violence and other additional issues (three questions); Psychological violence specifying four sections (verbal aggression, bullying/mobbing, sexual harassment, racial discrimination), each section containing 12 questions; Employer Information (five questions); Opinions on workplace violence (three questions). Respondents in the Jiao et al. study (2015) provided detailed information on the occurrence of inpatient aggression in the workplace in the previous year. At the same time, using this extensive tool, they provided further detailed information not only on the occurrence of aggression in the workplace and ways of dealing with it, but also racial discrimination and mobbing in the workplace. The authors reported that the WPV had good reliability (Cronbach $\alpha 0.87$ ).

\section{Discussion}

In their quantitative studies, the authors used various measuring tools to identify nurses' experiences of inpatient aggression (Table 1 Overview of research studies aimed at determining nurses' experience with inpatient aggression using measuring tools). For the purpose of measuring these experiences, several measuring tools have been developed, differing in their scope and the manner of recording respondents' answers. Differences in the development of the measuring tools assessing nurses' experiences of inpatient aggression are reflected in the diversity of the content of these tools; for example, the Survey of Violence Experienced by Staff, (German VersionRevised) (SOVES-GR) (Hahn et al., 2011) contains seven subscales, while the Perceptions of Prevalence of Aggression Scale (POPAS) (Nijman et al., 2005) investigates 15 forms of aggressive behavior, including self-aggression and sexual assault.

The tools also differ from one another in how they are administered, for example, the Violence and Aggression of Patients Scale (Lepiešová, Nemčeková, 2013) investigates whether nurses experienced inpatient aggression during a specified time period.

Vandersslott (1998) used the OAS (Over Aggression Scale, Yudofsky et al., 1986) to assess the degree of violence. Before the start of the research, its goal and purpose were explained to the respondents. Respondents were required to include the date and time of the incident and to complete questionnaires at three-month intervals over a 12 -month period, and to then submit them to the authors after completion (Vandersslott, 1998).

The largest measuring tool in terms of number of questions is the Workplace Violence in the Health Sector (WPV) (International Labor Office et al., 2003), which is also the most demanding in terms of administration. It investigates many related areas of aggression, not only from hospitalised patients, and also provides a considerable amount of information which cannot be used in its full scope when comparing the data on the occurrence of inpatient aggression gained using other measuring tools. A disadvantage of the questionnaire was how time-consuming it was for respondents to complete. In contrast, the VAPS (Lepiešová, Nemčeková, 2013), which included 11 questions aimed at identifying different forms of aggressive behavior of patients, is the shortest and administratively least demanding tool.

All of the tools used in the researched studies (Table 1 Overview of research studies aimed at determining nurses' experience with inpatient aggression using measuring tools) to identify nurses' experience of inpatient aggressive behavior showed good reliability.

In their studies (Table 1 Overview of research studies aimed at determining nurses' experience with inpatient aggression using measuring tools), the authors found and confirmed that nurses experienced a high rate of various manifestations of physical and non-physical inpatient aggression. The highest occurrence of inpatient verbal aggression (96.8\% of nurses) was reported by Lepiešová et al. (2015). Vanderslott (1998) reported a significant incidence of patient physical aggression towards nurses ( $88 \%$ of nurses) versus verbal aggression $(9 \%$ of nurses) or aggression towards objects. These significant differences in identified experiences of inpatient aggression could be due to differences in the specific questions relating to the various forms of aggression from patients. Several authors (Vanderslott, 1998; Nijman et al., 2005; Lepiešová et al., 2015) used measuring tools to investigate more specific forms of aggression, for example sexual aggression, threats, or physical aggression using a weapon.

The OAS (Over Aggression Scale, Yudofsky et al., 1986) describes four forms of aggression, determines four types of specific behavior in each, and thus can 
be described as the briefest tool in terms of aggression. The POPAS tool (The Perception of Prevalence of Aggression Scale questionnaire, Oud, 2001) is also one of the shorter tools measuring the incidence of aggression towards nurses. It contains 17 questions focusing on the type and frequency of aggression. The author estimates that completing the questionnaire should take respondents only 15 minutes (Oud, 2001).

Measuring the experience of nurses, and other categories of healthcare workers, of patient aggression using measuring tools helps us understand this experience and its implications, but does not provide precise information about the actual incidence of patient aggression in clinical practice (Iennaco et al., 2013).

\section{Limitation of study}

Our study was limited to the research studies available from the electronic databases of the University of Ostrava, and, furthermore, to those written in English.

\section{Conclusions}

Several measuring tools with good reliability have been developed to measure the experience of nurses of inpatient aggression. They allow us to record nurses' experience of a wide spectrum of aggressive behavior, although problems may arise when comparing the results of studies which have used measuring tools that differ in content, scope and administration. The tools mostly identify nurses' experience of inpatient aggression in the previous 12 months of their clinical practice. This may cause inaccuracies in the observed occurrence of patient aggression due to the fact that respondents may recall the aggressive behavior of patients inaccurately. Given that the tools compile subjective data on the experience of healthcare workers of patient aggression, their results cannot be regarded as a precise indication of the occurrence of aggression of hospitalized patients.

Measuring tools, provided they are valid and reliable, provide meaningful information about nurses' experience of various forms of inpatient aggression, but have their limitations that should be taken into account when interpreting the findings.

\section{Ethical aspects and conflict of interest}

The authors state that they have no conflict of interest, and affirm their observance of ethical rules when processing the results of the studies. of identifying different types and forms

\section{Author contribution}

Conception and design (ZK, MT), data analysis and interpretation (ZK), manuscript draft (ZK, MT), critical revision of the manuscript (MT), final article completion (ZK).

\section{References}

Arnetz JE. The Violent Incident Form (VIF): a practical instrument for the registration of violent incidents in the health care workplace. Work \& Stress. 1998;12(1):17-28.

Brůha D, Břeňková I, Štěpánková I. Reformy a změny v právním postavení zaměstnanců ve zdravotnictví a sociálních službách po roce 1989. Zdravotnictvi v České republice. 2005;3(8):124-132. (in Czech)

Čabanová $\mathrm{B}$, Dobiášová $\mathrm{K}$, Hnilicová $\mathrm{H}$. Násilí na pracovišti ve zdravotnictví v České republice $\mathrm{v}$ mezinárodním kontextu. Zdravotnictví $v$ České republice. 2005;3(8):116-123. (in Czech)

Gurková E, Gálliková D, Žiaková K, Grzywna T. Agresia pacientov a pracovná spokojnost' sestier vo vybranom zdravotníckom zariadení v Rakúsku. Ošetrovatel'stvo: teória, výskum, vzdelávanie. 2015;5(1):6-12. (in Slovak)

Hahn S, Müller M, Needham I, Dassen T, Kok G, Halfens RJ. Factors associated with patient and visitor violence experienced by nurses in general hospitals in Switzerland: a cross-sectional survey. Journal of Clinical Nursing. 2010;19(23-24):3535-3546.

Hahn S, Müller M, Needham I, Dassen T, Kok G, Halfens RJ. Measuring patient and visitor violence in general hospitals: feasibility of the SOVES-G-R, internal consistency and construct validity of the POAS-S and the POIS. Journal of Clinical Nursing. 2011;20(17-18):2519-2530.

Hahn S, Hantikainen V, Needham I, Kok G, Dassen T, Halfens RJ. Patient and visitor violence in the general hospital, occurrence, staff interventions and consequences: a cross-sectional survey. Journal of Advanced Nursing. 2012;68(12):2685-2699.

Iennaco JD, Dixon J, Whittemore R, Bowers L. Measurement and monitoring of health care worker aggression exposure. The Online Journal of Issues in Nursing . 2013;18(1):3.

International Labour Office ILO, International Council of Nurses ICN, World Health Organisation WHO, Public Services International PSI. Joint Programme on Workplace Violence in the Health Sector: Workplace Violence in the Health Sector Country Case Studies Reserch Instruments, Survey Questionnaire English. Geneva; 2003. [cited 2017 Jul 8]. Available from: http://www.who.int/violence_injury_prevention/violence/inter personal/en/WVquestionnaire.pdf

Jiao M, Ning N, Li Y, Gao L, Cui Y, Sun H, Kang Z, Liang $\mathrm{L}, \mathrm{Wu} \mathrm{Q}$, Hao $\mathrm{Y}$. Workplace violence against nurses in Chinese hospitals: a cross-sectional survey. BMJ Open. 2015;5(3):e006719.

Lanza ML. The reactions of nursing staff to physical assault by a patient. Hospital and Community Psychiatry. 1983;34(1):44-47.

Lepiešová M, Čáp J, Žiaková K, Nemčeková M. Výskyt agresie pacientov voči sestrám- psychomterické vlastnosti meracieho nástroja. Ořetrovatel'stvo: teória, výskum, vzdelávanie. 2012;2(1):26-32. (in Slovak) 
Lepiešová $\mathrm{M}$, Nemčeková $\mathrm{M}$. Násilie a agresia voči sestrám pri výkone povolania. Sociológia. 2013;45(2):172-194. (in Slovak)

Lepiešová M, Tomagová M, Bóriková I, Farský I, Žiaková K, Kurucová R. Experience of nurses of in-patient aggression in the Slovak Republic. Central European Journal of Nursing and Midwifery. 2015;6(3):306-312.

Lepping P, Lanka SV, Turner J, Stanaway SE, Krishna M. Percentage prevalence of patient and visitor violence against staff in high-risk UK medical wards. Clinical Medicine: Journal of the Royal College of Physicians of London. 2013;13(6):543-546.

Magnavita N, Heponiemi T. Workplace violence against nursing students and nurses: an Italian experience. Journal of Nursing Scholarship. 2011;43(2):203-210.

Magnavita N. Workplace violence and occupational stress in healthcare workers: a chicken-and-egg situation - results of a six-year follow-up study. Journal of Nursing Scholarship. 2014;46(5):366-376.

Morrison EF. The measurement of aggression and violence in hospitalized psychiatric patients. International Journal of Nursing Studies. 1993;30(1):51-64.

Nijman H, Bowers L, Oud N, Jansen G. Psychiatric nurses' experiences of inpatient aggression. Aggressive Behavior. 2005;31(3):217-227.

Oud N. The Perceptions of Prevalence of Aggression Scale (POPAS) Questionnaire. Amsterdam: Netherlands; 2001 [cited 2017 Nov 12]. Available from: https://www.researchgate.net/profile/Nico_Oud/publication/2 70159849_The_Perception_of_Prevalence_of_Aggression_Sc ale_POPAS_Questionnaire/links/54a177900cf256bf8baf71c1/ The-Perception-of-Prevalence-of-Aggression-Scale-POPASQuestionnaire.pdf

Pekara J, Trešlová M. Prevence násilí v ošetřovatelství. Prevence úrazů, otrav a násilí. 2011;7(2):187-191. (in Czech)
Pekara J. Násilí a české ošetřovatelství. Florence. 2013;12:20-22. (in Czech)

Rippon TJ. Aggression and violence in health care professions. Journal of Advanced Nursing. 2000;31(2):452460.

Sato K, Wakabayashi T, Kiyoshi-Teo H, Fukahori H. Factors associated with nurses' reporting of patients' aggressive behavior: a cross-sectional survey. International Journal of Nursing Studies. 2013;50(10):1368-1376.

Silver JM, Yudofsky SC. The Overt Aggression Scale: overview and guiding principles. The Journal of Neuropsychiatry Clinical Neurosciences. 1991;3(2):S22-S29. Speroni KG, Fitch T, Dawson E, Dugan L, Atherton M. Incidence and cost of nurse workplace violence perpetrated by hospital patients or patient visitors. Journal of Emergency Nursing. 2014;40(3):218-228.

Stevenson KN, Jack SM, O'Mara L, LeGris J. Registered nurses' experiences of patient violence on acute care psychiatric inpatient units: an interpretive descriptive study. BMC Nursing. 2015;14:35.

Szkanderová M, Jarošová D. Výskyt agresivity ve zdravotnických zařízeních. Profese online. 2008;1(1):1-9. (in Czech)

Taylor JL, Rew L. A systematic review of the literature: workplace violence in the emergency department. Journal of Clinical Nursing. 2011;20(7-8):1072-1085.

Vanderslott J. A study of incidents of violence towards staff by patients in an NHS Trust hospital. Journal of Psychiatric and Mental Health Nursing. 1998;5(4):291-298.

Yudofsky SC, Silver JM, Jackson W, Endicott J, Williams D. The Overt Aggression Scale for the objective rating of verbal and physical aggression. American Journal of Psychiatry. 1986;143(1):35-39.

Zacharová E. Agresivní pacient v klinické praxi zdravotníků. Interní medicína pro praxi. 2009;11(10):471. (in Czech) 